SEEING your accoint of the aurora of February 4 in NATURE of the 22nd, reminds me that on the evening of the 4 th $I$ was riding from Cambridge to Coldwell, in Ohio, and between six and seven o'clock saw a most brilliant display of auroral light in the southern quarter of the sky. Brilliant streamers skot up past the zenith, while the whole southern portion of the sky was brightly illuminated with a corruscating rose-coloured light.

Marietta, Ohio., March 15

A. J. WARNER

\section{Morse on Terebratulina}

I HAVE just read the very kind notice of my paper* in the pages of your journal from the pen of Mr. K. R. Lankester. I hasten, however, to remove one impression conveyed in the following sentence, respecting the opinions I hold as to the Annelidan affinities of the Brachiopods:-

"We are not sure whether Mr. Morse adheres to this startling proposition."

I trust the long delay in publishing the results of my studies on this interesting class will lead no one to suppose that $I$ have yet seen reason to modify the position $I$ took two years ago regarding their position in the animal kingdom. On the contrary, continued investigation has brought out many new points of in. terest, and now 1 hope, ere my paper is published, to present the embryology of some one of them.

I had studied our native Terebratulina, its structure, as. well as its early stages, and through the kindness of Prof. Verrill, had studied Discina leevis (upon which I hope soon to publish).

Mr. Lankester, as the author of many valuable memoirs requiring much skill and patient labour, will fully appreciate the time and care necessary in work of this kind.

As to $\mathrm{my}$ being unduly impressed at the sight of living Lingula, I may say, in justice to myself, and my friends will testify to it, my opinions were fully formed before I ever saw Lingula at all. With the caution that is requisite for every one, if he does not wish to supplement his paper with a correction of errors, a way of doing things altogether too frequent in this country, I deemed it important to study living Lingula before publishing. It was impossible for me to go half-way round the worid for it. And as three specimens of another species have been found on the coast of North Carolina, I determined to go there. A trip of nearly a thousand miles brought me to its waste of drifting sands.

Thoroughly convinced as to the correctness of my views, and these views of sufficient strength to convince my co-labourers, $\mathrm{Mr}$. Lankester will understand my enthusiasm when, after week's fruitless search under a blazing sun, and an almost hopeless task, I found Lingula, not as we have always supposed attached by its peduncle, but living in the sand; precisely like many tubicolous worms, building a true sand tube, and when liberated from it crawling and burrowing by means of its setae and with all these welcome characters it should greet me with red blood. Not that I lay. great stress. on any one of these characters, but having made my deductions from the most common form, Terebratulina; one can readily understand the bearing of such unexpected characters in this little Lingula.

Mr. Lankester will admit that the Vermian lumber-room has some orderly compartments; into one of those I place the Brachiopods far away from all Molluscan odours.

The distinguished naturalist, Prof. Steenstrup, informs me that he has long taught his classes at the University of Copenhagen that the Brachiopods were true.Annelids, and that my views are thoroughly endorsed by him. To him, therefore, and not to me as had been supposed, belongs the priority of this discovery.

I only ask a little patience till my complete paper is published on the Brachiopods as a division of Annelida, in which I shall give appropriate figures, and my reasons in full for the position I have taken.

Salem, Mass., U.S.A., March i4

\section{On the Colour of a Hydrogen Flame}

WHEN hydrogen and oxygen are burned together, it is well known that the flame produced is almost non-luminous; it always, however, exhibits an unmistakeably blue tinge.

The small illuminative power is generally referred to the " absence of solid particles." This view, it appears to me, draws a too rigid line of demarcation between the atoms of carbon in an ordinary gas-coal flame and the atoms of hydrogen in that of the oxyhydrogen. The cause of the phenomenon does not depend so much on the solidity as it does on the time of oscillation of the particles which constitute the flame. Water parcicles in all their states of aggregation preserve the same time of oscillation-extra red; hence a hydrogen flame should be perfectly invisible whatever may be the "solidity" or density of its particles.

But the flame is not invisible, and, what is still more remarkable, the colour which it does exhibit is found to belong to the most refrangible end of the spectrum. To explain this strange phenomenon, it appears to me that it is necessary to invoke : a state in the ether particles siwilar to that which Helmholtz has shown to exist in air ; and which is this:-A tuning-fork "vigorously struck against a pad emits the octave of its fundamental note." Now, the first overtone of a tuning fork is produced by vibrations about $6 \frac{1}{4}$ times as rapid as the fundamental; the octave, therefore, is not an overtone of the fork-it is produced solely in consequence of the fact that the inilial disturbance is great in proportion to the distance of the air particles from one another, secundary waves being produced whose periods are twice as rapid as those of the fundamental.

The amplitude of the particles in a hydrogen flame is known to be very great, and hence it seems probable that an effect may result from the disturbance thus created in the ether, analogous to that in the case of air, i.e., associated with the fundamental vibrations of the hydrogen flame we have their octave, which would obviously be within the visual range, and currespond very closely, if not exactly, with the colour actually observed.

Should this surmise prove correct we have plainly an easy means by which we can determine the wave-length of those extra-red rays which are absorbed by water.

Hartley Institution, Southampton, March 26

A. G. Meeze

P.S.-May not the great actinic power of the electric light be due in a great measure to the secondary waves produced by the magnitude of the disturbing force?

\section{VESTIGES OF THE GLACIAL PERIOD IN NORTH-EASTEKN ANATOLIA}

A TTENTION was drawn to this subject in a lecture given on March 25 at the Royal Geographical Society by the Eastern traveller Mr. W. Gifford Palgrave, at present British Consul for the northern coast of Asia Minor. The facts which he mentioned had been principally observed by him during a tour on duty to the interior about two years ago; and the line of route lay from the town of Trebizond on the sea coast to that of Erzinghian on the Upper Euphrates.

The phenomena themselves were divided into two classes : the one referable to the highlands which he had then traversed, the other to their marginal region.

These highlands are situated on or near the 40 th parallel of latitude, and extend between the 37 th and 44 th of longitude, east and west ; their average breadth being about tifty miles, and their elevation varying from 3,000 to 9,000 feet above the sea. They constitute the great watershed of Eastern Anatolia; the rivers to the south of them flowing into the Persian Gulf, and those to the north into the Black Sea. To the west is the basin of the Halys, to the east that of the Caspian.

The road leading across this plateau towards Erzinghian, mounts up to it by a defile named "Ketcheh-Dereh" or "Goats' Valley," Here, at a height of about 5,400' feet above the sea, Mr. Palgrave came on the lower extremity of a large moraine, piled up to a height of more than twenty feet, and broad in proportion. Following it for a distance of nearly half a mile, he found that when it had reached between 400 and 500 feet higher up the slope, it forked into two lesser branches; continued each a good way further into the rising undulations of the table-land.

The plateau itself bore every mark of having lain under a thick ice-coating; its eminences and irregularities all bearing the "moutonnée" character impressed by glacia. action; while it was also frequently strewn with detached 